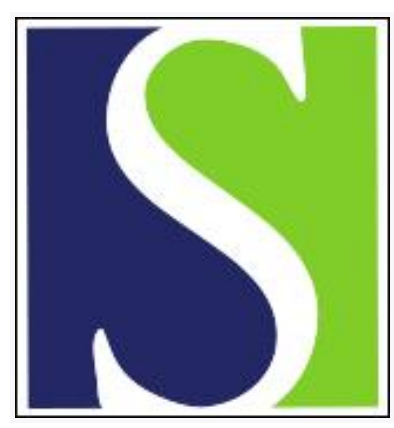

Scand J Work Environ Health 1995;21(2):134-142

https://doi.org/10.5271/sjweh.20

Issue date: Apr 1995

Psychosocial factors at work in relation to back and limb disorders

by Leino PI, Hänninen V

The following articles refer to this text: 2001;27(4):268-278;

2004;30(1):47-55; 2012;38(3):282-290

Key terms: follow-up; low-back pain; MSD; musculoskeletal disorder; neck pain; physical workload; psychosocial factor; shoulder pain; stress; work satisfaction

This article in PubMed: www.ncbi.nlm.nih.gov/pubmed/7618059 


\title{
Psychosocial factors at work in relation to back and limb disorders
}

\author{
by Päivi I Leino, MD,' Vilma Hänninen, LicSocSci, ${ }^{2}$
}

\author{
Leino PI, Hänninen V. Psychosocial factors at work in relation to back and limb disorders. Scand $J$ Work \\ Environ Health 1995;21:134-42.
}

\begin{abstract}
Objectives This study was a 10-year follow-up of the associations between work content, work control, social relationships at work, mental overstrain, physical work load, and musculoskeletal morbidity in the neck, shoulder and upper limb region, the low back, and the lower limbs among workers in the metal industry.

Methods A sample of 902 blue- and white-collar employees were studied. Measurements were made twice at a 10-year interval by questionnaire and clinical examination.

Results At the beginning of the study, mental overstrain showed several associations with both the symptoms and the findings. The other psychosocial factors were the most consistently associated with the symptoms in the region of the neck, shoulder, and upper limbs and also in the lower-limb region among the middle-aged men. Prospectively, the social relations and the work content scores predicted the change in several morbidity scores. The associations were independent of physical work load.

Conclusions Work-related psychosocial factors were associated with, and predicted, the change in the occurrence of musculoskeletal disorders when age, gender, social class, and physical work load were controlled for.
\end{abstract}

Key terms follow-up, low-back pain, musculoskeletal disorders, neck-shoulder pain, psychosocial factors, physical work load, stress, work satisfaction.

The complex and multifactorial origin of common musculoskeletal disorders, such as neck-shoulder and lowback pain, is currently widely accepted, although the specific nature of the etiologic models adhered to varies considerably (1). During the past few years, several authors have tried to determine the contribution of psychosocial factors to musculoskeletal morbidity $(2-3)$.

A consistent finding in the literature seems to be the covariation of distress symptoms with those of the musculoskeletal system (2). There are also several reports of a relationship between musculoskeletal disorders and work that is mentally too straining or demanding (4-6), fatigue or exhaustion from work $(4,7)$, or general work satisfaction (4-5, 7-8).

More specific psychological and social features of work that influence the occurrence of musculoskeletal disorders have also been identified. Winkleby et al (9) reported a gradient of increased musculoskeletal trouble for city bus drivers with increased levels of job-related problems, such as rule violations, danger situations, problems with passengers and co-workers, and job structure. Uninteresting tasks and poor social support at work added to the risk of low-back and neck pain in a mixed population of occupational health service users (10). A sum index of monotony at work, hurriedness, and worry about making mistakes was associated with chronic neck pain in a Finnish population sample when physical work load and life-style were controlled for (11). Negative relations with workmates and supervisors have been observed to be associated with back disorders in both a cross-sectional study (6) and prospective studies (12-13).

The existing literature has some restrictions. The main focus has been on low-back pain and its predictors, and other parts of the musculoskeletal system have been relatively neglected. Prospective studies are few. It is not often made clear whether the observed associations might be biased because of uncontrolled effects of physical work load or other factors related to social class.

The objective of this investigation was to study a sample of an industrial population to determine whether such factors as psychological work content, control over one's work, social relationships at the workplace, and mental overstrain from work are associated with disorders of the neck, shoulder and upper-limb region, the low back, or the lower limbs. In addition, we wished to study whether the possible associations were independent of physical work load and sociodemographic characteris-

1 LEL Employment Pension Fund, Health Research Unit, Helsinki, Finland.

2 Department of Sociology and Social Psychology, University of Tampere, Finland.

Reprint requests to: Dr P Leino, LEL Employment Pension Fund, Health Research Unit, PO Box 20, FIN-00240 Helsinki, Finland. 
tics. The investigation was conducted as part of a large prospective study on work conditions, life-style, mental well-being, and physical health in a cohort of metal industry employees (14).

\section{Subjects and methods}

\section{Data collection}

The study sample was obtained from the employees of if Valmet engineering factories (in Jyväskylä, Finland) hat produced paper mills, tractors, engines, rifles, gauges, and the like. The number of employees was 4570 in 1973, of which those who had been employed by Valmet for at least 15 months at the beginning of the study were considered (ie, 2653 subjects). For the sampling the employees were stratified into groups according to gender, age (three groups: born in 1925 or earlier, born between 1926 and 1945, and born in 1946 or later), and occupational class (four groups: managers, office personnel, skilled workers, and semi-skilled workers). A systematic nonproportional sampling was made. For the present analyses, the managers and office personnel were pooled into a white-collar group and the skilled and semi-skilled workers into a blue-collar group.

The sample consisted of 902 subjects at the beginning of the study (142 white-collar and 151 blue-collar women, 253 white-collar and 356 blue-collar men). In a reexamination 10 years later 654 subjects ( $77 \%$ of those alive) took part. There were no significant differences in the type of work, original health status, or age of the male participants and those lost to follow-up (14). The mean age of the women that did not take part in the second examination was somewhat lower than that of the participants. The prospective analyses included the subjects that were still occupationally active at the end of the follow-up, a total of 411 subjects (117 white-collar and 149 blue-collar men, 83 white-collar and 62 blue-collar women).

Data were collected by a questionnaire sent in January each year. Data missing from the questionnaire were obtained during the spring in interviews in a health examination that included a clinical assessment of the musculoskeletal system.

\section{Psychosocial factors at work}

The psychosocial factors at work were assessed by questionnaire. Four sum indices were constructed (appendix 1).

\section{Physical work load}

The questionnaire item "What is your work like?" assessed the overall physical strenuousness and described the following four grades: (i) sitting work (mainly sitting at a table or by a machine, doing light work with the hands), (ii) light physical work (mainly standing without heavy working movements or sitting with heavy movements with the hands or moving about without heavy loads) (iii) physical work of medium heaviness (constant light work movements, such as light lifting or turning of handles or levers, or constant standing or walking, or alternating between sitting and doing heavy work movements), (iv) heavy physical work (constant or almost constant heavy work movements such as hammering, forging, loading with hands, wheeling, etc).

\section{Musculoskeletal morbidity}

Two types of musculoskeletal morbidity indices were constructed, those based on symptoms reported in the questionnaire and those based on a prestructured examination by a physiotherapist (appendix 2). Indices reflecting the morbidity of three anatomically distinct areas, and overall sum scores, were used.

Two trained physiotherapists performed the clinical examinations. Joints and muscles were palpated and restrictions in the movements of joints and the spine, mainly in active movement, were measured (14). The following guidelines were used (15): $0=$ symptomless, 1 = pain in the movement of the joint or in palpation or in both, 2 = range of movement restricted by 25 to $50 \%$, $4=$ restriction by more than $50 \%$. For the cervical spine the fourth grade was restriction by more than 60 degrees plus a positive foramen intervertebralis sign, whereas for the lumbosacral spine it was marked inflexibility or neurological signs in the lower extremities (positive Lasegue's or Ely's test). Myalgia in the extremities was scored from $0=$ no to $2=$ bilaterally, and myalgia of the trapezius muscle was scored from $0=$ no to $1=$ yes

The intraobserver reliability of the total musculoskeletal findings score was assessed at the beginning of the investigation in a sample of 54 subjects examined a second time within two weeks. The reliability (r) was 0.93 for the men and 0.77 for the women. At follow-up, 54 subjects had a second examination by the other physiotherapist directly after the first examination. The kappa coefficients of some items were as follows: 0.64 (left humeroscapular joint), 0.61 (cervical spine), 0.55 (myalgia of the upper arm), and 0.40 (lumbosacral spine). The subjects were distributed to the examiners rather equally by the sampling strata.

\section{Statistical methods}

Differences in the work-related factors and morbidity by gender and occupational class were studied by a two-way analysis of variance. The intercorrelations between the work-related factors, as well as their 10-year autocorrela- 
tions, were assessed. The associations between the psychosocial factors and musculoskeletal morbidity at the beginning of the investigation were studied by partial correlation coefficients in three age groups, physical load being controlled for. Prospectively, the analogous morbidity score from the beginning of the study and age were also controlled for.

The simultaneous associations between morbidity and the psychosocial and physical work-load variables, age (years), gender, and occupational class were assessed by multiple regression analysis. First, forward stepwise models were calculated with the statistical significance criterion $\mathrm{P}=0.05$ for inclusion. Second, ordinary regression analyses were made with the variables that had entered the stepwise models, to enable comparison of the standardized regression coefficients.

The distributions of the morbidity variables were positively skewed. Skewness coefficients (SE) of the magnitude of $1.98(0.08)$ and $1.64(0.10)$ were calculated for the total symptoms score at the beginning of the study and at follow-up, respectively, and, similarly, the coefficients $2.29(0.08)$ and $0.91(0.10)$ were calculated for the findings score. Logarithmic transformation of the scores reduced their skewness, but it did not substantially alter the results. Because of an easier interpretation of the original scores we decided to use no transformation.

\section{Results}

The averages of the psychosocial factors and physical work load by gender and occupational class are presented in table 1 . All of the variables except the overstrain index were higher (ie, more adverse) among the blue-collar workers than among the white-collar staff. There were also differences by gender. The interrelationships between the work-load scores and age are shown for the total sample in table 2. The highest correlations were observed between the work control score on one hand and the work content and social relations indices on the other. Musculoskeletal morbidity varied by occupational class and gender, as shown in table 3.

The relationships of the psychosocial factors with morbidity among men at the beginning of the study are presented in table 4 . The morbidity of the upper back and the limbs was more consistently associated with psychosocial work load than low-back morbidity was. Among the middle-aged workers, the associations between the work content, work control, and social relations scores and the symptoms from the upper back and the limbs were clear. Mental overstrain was associated with morbidity among the youngest and the oldest, especially. All of the work-load scores were associated with the clinical findings of the neck, shoulder and upper-limb region in the older blue-collar men.

Table 1. Psychosocial and physical load at work at the beginning of the study, by occupational class and gender. (ANOVA = analysis of variance)

\begin{tabular}{|c|c|c|c|c|c|c|c|c|c|c|}
\hline \multirow[t]{3}{*}{ Load } & \multicolumn{4}{|c|}{ Men } & \multicolumn{4}{|c|}{ Women } & \multicolumn{2}{|c|}{ ANOVA } \\
\hline & \multicolumn{2}{|c|}{$\begin{array}{l}\text { White- } \\
\text { collar } \\
(N=253)\end{array}$} & \multicolumn{2}{|c|}{$\begin{array}{c}\text { Blue- } \\
\text { collar } \\
(N=356)\end{array}$} & \multicolumn{2}{|c|}{$\begin{array}{l}\text { White- } \\
\text { collar } \\
(N=144)\end{array}$} & \multicolumn{2}{|c|}{$\begin{array}{c}\begin{array}{c}\text { Blue- } \\
\text { collar } \\
(N=149)\end{array}\end{array}$} & \multirow[t]{2}{*}{$\begin{array}{c}\text { Gender } \\
\text { (P-value) }\end{array}$} & \multirow{2}{*}{$\begin{array}{c}\text { Occupa- } \\
\text { pational } \\
\text { class } \\
\text { (P-value) }\end{array}$} \\
\hline & Mean & $S D$ & Mean & SD & Mean & SD & Mean & SD & & \\
\hline Work content & 11.4 & 3.8 & 15.9 & 4.4 & 15.2 & 4.3 & 17.8 & 4.7 & 0.000 & 0.000 \\
\hline Work control & 10.8 & 3.3 & 14.0 & 2.8 & 13.4 & 3.0 & 13.9 & 2.9 & 0.000 & 0.000 \\
\hline $\begin{array}{l}\text { Social } \\
\text { relationships }\end{array}$ & 12.5 & 3.2 & 14.4 & 3.6 & 13.7 & 3.6 & 14.0 & 3.7 & 0.159 & 0.000 \\
\hline Overstrain & 9.4 & 2.2 & 8.1 & 2.4 & 8.0 & 2.7 & 8.1 & 2.1 & 0.000 & 0.000 \\
\hline Physical load & 1.2 & 0.57 & 2.7 & 0.85 & 1.2 & 0.56 & 2.3 & 1.0 & 0.000 & 0.001 \\
\hline
\end{tabular}

Table 2. Pearson correlation coefficients between the measures of psychosocial and physical load at work and age for the total sample at the beginning of the study.

\begin{tabular}{|c|c|c|c|c|c|c|}
\hline & 1 & 2 & 3 & 4 & 5 & 6 \\
\hline 1 Work content & - & & & & & \\
\hline 2 Work control & $0.48^{* * *}$ & - & & & & \\
\hline 3 Social relations & $0.34^{* * *}$ & $0.42^{* * *}$ & - & & & \\
\hline 4 Overstrain & $-0.13^{* * *}$ & -0.06 & $0.14^{* * *}$ & - & & \\
\hline 5 Physical load & $0.30^{\star * *}$ & $0.21^{* * *}$ & $0.11^{* * *}$ & $-0.07^{*}$ & - & \\
\hline 6 Age & $-0.11^{* * *}$ & $-0.07^{*}$ & $-0.19^{* * *}$ & $0.10^{* *}$ & 0.05 & - \\
\hline
\end{tabular}

${ }^{\star} \mathrm{P}<0.05,{ }^{* \star} \mathrm{P}<0.01,{ }^{* \star} \mathrm{P}<0.001$. 
Table 3. Musculoskeletal morbidity at the beginning of the study and after the follow-up (age and the analogous morbidity score at the beginning of the study as covariates) by gender and occupational class. (ANOVA = analysis of variance)

\begin{tabular}{|c|c|c|c|c|c|c|c|c|c|c|}
\hline & \multicolumn{4}{|c|}{ Men } & \multicolumn{4}{|c|}{ Women } & \multicolumn{2}{|c|}{ ANOVA } \\
\hline & \multicolumn{2}{|c|}{$\begin{array}{l}\text { White- } \\
\text { collar }\end{array}$} & \multicolumn{2}{|c|}{$\begin{array}{l}\text { Blue- } \\
\text { collar }\end{array}$} & \multicolumn{2}{|c|}{$\begin{array}{l}\text { White- } \\
\text { collar }\end{array}$} & \multicolumn{2}{|c|}{$\begin{array}{l}\text { Blue- } \\
\text { collar }\end{array}$} & \multirow[t]{2}{*}{$\begin{array}{l}\text { Gender } \\
\text { (P-value) }\end{array}$} & \multirow{2}{*}{$\begin{array}{c}\text { Occupa } \\
\text { pationa } \\
\text { class } \\
\text { (P-value }\end{array}$} \\
\hline & Mean & SD & Mean & SD & Mean & SD & Mean & $\mathrm{SD}$ & & \\
\hline \multicolumn{11}{|c|}{ Beginning of study } \\
\hline \multicolumn{11}{|c|}{ Neck-shoulders-upper limbs } \\
\hline $\begin{array}{l}\text { Symptoms } \\
\text { Findings }\end{array}$ & $\begin{array}{r}12.9 \\
0.8\end{array}$ & $\begin{array}{l}3.6 \\
1.4\end{array}$ & $\begin{array}{r}14.6 \\
1.3\end{array}$ & $\begin{array}{l}5.2 \\
2.1\end{array}$ & $\begin{array}{r}14.5 \\
1.3\end{array}$ & $\begin{array}{l}4.4 \\
1.8\end{array}$ & $\begin{array}{r}17.1 \\
2.5\end{array}$ & $\begin{array}{l}6.2 \\
2.8\end{array}$ & $\begin{array}{l}0.000 \\
0.000\end{array}$ & $\begin{array}{l}0.000 \\
0.000\end{array}$ \\
\hline \multicolumn{11}{|l|}{ Low back } \\
\hline $\begin{array}{l}\text { Symptoms } \\
\text { Findings }\end{array}$ & $\begin{array}{l}3.9 \\
0.4\end{array}$ & $\begin{array}{l}1.4 \\
0.69\end{array}$ & $\begin{array}{l}4.6 \\
0.6\end{array}$ & $\begin{array}{l}2.1 \\
0.93\end{array}$ & $\begin{array}{l}4.2 \\
0.4\end{array}$ & $\begin{array}{l}1.7 \\
0.69\end{array}$ & $\begin{array}{l}4.8 \\
0.5\end{array}$ & $\begin{array}{l}2.1 \\
0.62\end{array}$ & $\begin{array}{l}0.092 \\
0.434\end{array}$ & $\begin{array}{l}0.000 \\
0.007\end{array}$ \\
\hline \multicolumn{11}{|l|}{ Lower limbs } \\
\hline $\begin{array}{l}\text { Symptoms } \\
\text { Findings }\end{array}$ & $\begin{array}{r}14.9 \\
0.7\end{array}$ & $\begin{array}{l}4.3 \\
1.5\end{array}$ & $\begin{array}{r}15.7 \\
1.0\end{array}$ & $\begin{array}{l}5.0 \\
1.9\end{array}$ & $\begin{array}{r}14.9 \\
1.2\end{array}$ & $\begin{array}{l}3.7 \\
2.0\end{array}$ & $\begin{array}{r}16.8 \\
2.0\end{array}$ & $\begin{array}{l}5.5 \\
2.7\end{array}$ & $\begin{array}{l}0.096 \\
0.000\end{array}$ & $\begin{array}{l}0.000 \\
0.000\end{array}$ \\
\hline \multicolumn{11}{|l|}{ Follow-up } \\
\hline \multicolumn{11}{|c|}{ Neck, shoulders, upper limbs } \\
\hline $\begin{array}{l}\text { Symptoms } \\
\text { Findings }\end{array}$ & $\begin{array}{r}13.8 \\
2.8\end{array}$ & $\begin{array}{l}3.7 \\
2.8\end{array}$ & $\begin{array}{r}15.0 \\
4.0\end{array}$ & $\begin{array}{l}4.2 \\
3.7\end{array}$ & $\begin{array}{r}16.3 \\
3.3\end{array}$ & $\begin{array}{l}4.8 \\
2.4\end{array}$ & $\begin{array}{r}18.7 \\
3.2\end{array}$ & $\begin{array}{l}6.8 \\
3.3\end{array}$ & $\begin{array}{l}0.000 \\
0.504\end{array}$ & $\begin{array}{l}0.000 \\
0.076\end{array}$ \\
\hline \multicolumn{11}{|l|}{ Low back } \\
\hline $\begin{array}{l}\text { Symptoms } \\
\text { Findings }\end{array}$ & $\begin{array}{l}4.1 \\
0.76\end{array}$ & $\begin{array}{l}1.5 \\
1.1\end{array}$ & $\begin{array}{l}4.3 \\
1.1\end{array}$ & $\begin{array}{l}1.8 \\
1.2\end{array}$ & $\begin{array}{l}4.6 \\
0.86\end{array}$ & $\begin{array}{l}1.8 \\
0.94\end{array}$ & $\begin{array}{l}5.2 \\
1.1\end{array}$ & $\begin{array}{l}2.3 \\
1.2\end{array}$ & $\begin{array}{l}0.000 \\
0.777\end{array}$ & $\begin{array}{l}0.023 \\
0.017\end{array}$ \\
\hline \multicolumn{11}{|l|}{ Lower limbs } \\
\hline $\begin{array}{l}\text { Symptoms } \\
\text { Findings }\end{array}$ & $\begin{array}{r}14.5 \\
1.9\end{array}$ & $\begin{array}{l}4.2 \\
2.1\end{array}$ & $\begin{array}{r}14.9 \\
3.1\end{array}$ & $\begin{array}{l}4.3 \\
2.6\end{array}$ & $\begin{array}{r}15.3 \\
2.0\end{array}$ & $\begin{array}{l}4.0 \\
3.1\end{array}$ & $\begin{array}{r}17.1 \\
2.3\end{array}$ & $\begin{array}{l}5.9 \\
3.6\end{array}$ & $\begin{array}{l}0.001 \\
0.176\end{array}$ & $\begin{array}{l}0.013 \\
0.003\end{array}$ \\
\hline
\end{tabular}

a Number of subjects: white-collar men: 253, blue-collar men: 356, white-collar women: 144, blue-collar women: 149 .

- Number of subjects: white-collar men: 117, blue-collar men: 149, white-collar women: 83 , blue-collar women: 62 .

The associations among the women were less consistent than among the men. There were, however, many similarities in the associations.

Prospectively the pattern of the relationships by age group was no longer visible. The social relations score yielded the most consistent associations (table 5). Among the blue-collar women, the change in the low-back findings were predicted by all of the indices of psychosocial work load.

Physical load was associated with musculoskeletal morbidity, especially among the older blue-collar men at the beginning of the study (up to $r=0.30$ ). Prospectively, physical load was not associated with morbidity.

The multiple regression models for the total sum of the morbidity scores are presented in table 6. Mental overstrain and work content entered the models of both the symptoms and findings at the beginning of the study, together with physical load and the sociodemographic variables. Prospectively, the social relations score of the first examination predicted the 10-year change in the musculoskeletal symptoms and findings.

The models for the neck, shoulder and upper-limb area were similar to the total models at the beginning of the study. Fewer variables entered the models for the other anatomical regions. The change in the low-back findings was predicted both by the social relations and the work content score.

\section{Discussion}

We have shown that pain in different parts of the musculoskeletal system, as well as clinical findings made by a physiotherapist, were associated with psychosocial factors at work in a sample of industrial employees. There were similarities in the associations from one anatomical region to another. This finding suggests a general musculoskeletal responsivity to mental stress, a result supported also by previous findings $(1,16)$.

The measures of psychosocial work load described the employees' personal experiences of the psychological work content, control over one's own work, the social milieu at work, and work-related mental overstrain. When judged from the negative autocorrelations over time (table 7), mental overstrain at work was an incentive for an active change in work load. The stability of the other psychosocial aspects of work was better among the white-collar workers than among the bluecollar ones. 
Table 4. Associations (partial correlation coefficients) between psychosocial factors at work and musculoskeletal morbidity among the men at the beginning of the study by occupational class and age group (physical load controlled for).

\begin{tabular}{|c|c|c|c|c|}
\hline \multirow[t]{2}{*}{ Age group } & \multicolumn{2}{|c|}{ White-collar } & \multicolumn{2}{|c|}{ Blue-collar } \\
\hline & Symptoms & Findings & Symptoms & Findings \\
\hline \multicolumn{5}{|c|}{ Neck, shoulders, upper limbs } \\
\hline \multicolumn{5}{|c|}{ Born in 1946 or later ${ }^{a}$} \\
\hline $\begin{array}{l}\text { Work content } \\
\text { Work control } \\
\text { Social relations } \\
\text { Overstrain }\end{array}$ & $\begin{array}{l}0.00 \\
0.08 \\
0.30^{*} \\
0.39^{* *}\end{array}$ & $\begin{array}{l}0.05 \\
0.14 \\
0.00 \\
0.10\end{array}$ & $\begin{array}{l}0.12 \\
-0.01 \\
-0.06 \\
0.27^{* *}\end{array}$ & $\begin{array}{r}0.06 \\
-0.09 \\
-0.06 \\
-0.02\end{array}$ \\
\hline \multicolumn{5}{|l|}{ Born in 1926-1945 } \\
\hline $\begin{array}{l}\text { Work content } \\
\text { Work control } \\
\text { Social relations } \\
\text { Overstrain }\end{array}$ & $\begin{array}{l}0.44^{* * *} \\
0.33^{* * *} \\
0.24^{* *} \\
0.14\end{array}$ & $\begin{array}{l}0.10 \\
0.03 \\
0.15 \\
0.16\end{array}$ & $\begin{array}{l}0.16 \\
0.18^{*} \\
0.23^{* \star} \\
0.16\end{array}$ & $\begin{array}{l}0.06 \\
0.14 \\
0.11 \\
0.08\end{array}$ \\
\hline \multicolumn{5}{|c|}{ Born in 1925 or earlier } \\
\hline $\begin{array}{l}\text { Work content } \\
\text { Work control } \\
\text { Social relations } \\
\text { Overstrain }\end{array}$ & $\begin{array}{c}-0.07 \\
0.01 \\
-0.10 \\
0.41^{\star \star \star}\end{array}$ & $\begin{array}{c}0.27^{\star} \\
0.17 \\
-0.01 \\
0.08\end{array}$ & $\begin{array}{l}0.03 \\
0.14 \\
0.11 \\
0.32^{\star * *}\end{array}$ & $\begin{array}{l}0.21^{*} \\
0.22^{*} \\
0.17^{*} \\
0.30^{* * *}\end{array}$ \\
\hline \multicolumn{5}{|l|}{ Low back } \\
\hline \multicolumn{5}{|c|}{ Born in 1946 or later } \\
\hline $\begin{array}{l}\text { Work content } \\
\text { Work control } \\
\text { Social relations } \\
\text { Overstrain }\end{array}$ & $\begin{array}{r}0.18 \\
0.06 \\
0.05 \\
-0.05\end{array}$ & $\begin{array}{r}-0.17 \\
0.22 \\
0.20 \\
0.22\end{array}$ & $\begin{array}{l}0.12 \\
0.19^{*} \\
0.02 \\
0.16\end{array}$ & $\begin{array}{r}-0.03 \\
0.03 \\
-0.06 \\
0.13\end{array}$ \\
\hline \multicolumn{5}{|l|}{ Born in 1925-1945b } \\
\hline $\begin{array}{l}\text { Work content } \\
\text { Work control } \\
\text { Social relations } \\
\text { Overstrain }\end{array}$ & $\begin{array}{r}0.06 \\
-0.01 \\
-0.02 \\
0.09\end{array}$ & $\begin{array}{l}0.18^{*} \\
0.02 \\
0.21^{*} \\
0.09\end{array}$ & $\begin{array}{l}0.11 \\
0.11 \\
0.24^{* *} \\
0.31^{* * *}\end{array}$ & $\begin{array}{c}-0.04 \\
0.07 \\
0.10 \\
0.20^{*}\end{array}$ \\
\hline \multicolumn{5}{|c|}{ Born in 1925 or earlier } \\
\hline $\begin{array}{l}\text { Work content } \\
\text { Work control } \\
\text { Social relations } \\
\text { Overstrain }\end{array}$ & $\begin{array}{c}-0.19^{*} \\
-0.06 \\
0.02 \\
0.05\end{array}$ & $\begin{array}{l}0.19 \\
0.24^{*} \\
0.12 \\
0.02\end{array}$ & $\begin{array}{l}0.11 \\
0.06 \\
0.00 \\
0.22^{*}\end{array}$ & $\begin{array}{l}0.16 \\
0.19^{\star} \\
0.10 \\
0.13\end{array}$ \\
\hline \multicolumn{5}{|l|}{ Lower limbs } \\
\hline \multicolumn{5}{|c|}{ Born in 1946 or later ${ }^{a}$} \\
\hline $\begin{array}{l}\text { Work content } \\
\text { Work control } \\
\text { Social relations } \\
\text { Overstrain }\end{array}$ & $\begin{array}{c}-0.21 \\
0.03 \\
0.28^{\star} \\
0.28^{\star}\end{array}$ & $\begin{array}{c}0.07 \\
0.14 \\
-0.26^{\star} \\
-0.11\end{array}$ & $\begin{array}{l}0.17^{\star} \\
0.02 \\
-0.01 \\
0.24^{* *}\end{array}$ & $\begin{array}{l}0.01 \\
0.00 \\
-0.22^{\star *} \\
0.25^{\star *}\end{array}$ \\
\hline \multicolumn{5}{|l|}{ Born in 1926-1945 } \\
\hline $\begin{array}{l}\text { Work content } \\
\text { Work control } \\
\text { Social relations } \\
\text { Overstrain }\end{array}$ & $\begin{array}{l}0.34^{* * *} \\
0.27^{* *} \\
0.31^{* * *} \\
0.15\end{array}$ & $\begin{array}{r}0.14 \\
0.06 \\
0.16 \\
-0.05\end{array}$ & $\begin{array}{l}0.24^{* *} \\
0.11 \\
0.44^{* * *} \\
0.22^{*}\end{array}$ & $\begin{array}{l}0.17^{*} \\
0.06 \\
0.14 \\
0.13\end{array}$ \\
\hline \multicolumn{5}{|c|}{ Born in 1925 or earlierc } \\
\hline $\begin{array}{l}\text { Work content } \\
\text { Work control } \\
\text { Social relations } \\
\text { Overstrain }\end{array}$ & $\begin{array}{r}0.08 \\
0.14 \\
-0.06 \\
-0.04\end{array}$ & $\begin{array}{l}0.04 \\
0.07 \\
0.03 \\
0.00\end{array}$ & $\begin{array}{c}0.20^{\star} \\
-0.12 \\
-0.07 \\
0.19^{\star}\end{array}$ & $\begin{array}{l}0.20^{\star} \\
0.07 \\
0.09 \\
0.17^{*}\end{array}$ \\
\hline
\end{tabular}

a Number of subjects: white-collar: 52 , blue-collar: 120 .

b Number of subjects: white-collar 122, blue-collar 117

c Number of subjects: white-collar 79, blue-collar 119.

${ }^{*} \mathrm{P}<0.05,{ }^{* *} \mathrm{P}<0.01,{ }^{* * *} \mathrm{P}<0.001$.

Pain is by definition a subjective experience. The clinical examination that we used represents a step towards objectivity (or intersubjectivity) from the purest symptom level. The subjectivity of the measures raises the question of the nature of the observed relationship.
Are distressing features of work causes of musculoskeletal pain disorder? Or do subjects in pain perceive their work as less satisfactory than their fellow workers just because of pain?

Social interaction at work and some psychologi- 
Table 5. Associations between psychosocial factors at work and the 10-year change of musculoskeletal morbidity, by gender and occupational class. Partial correlation coefficients (age, the analogous morbidity score at the beginning of the study and physical load controlled for).

\begin{tabular}{|c|c|c|c|c|}
\hline \multirow[t]{2}{*}{ Gender } & \multicolumn{2}{|c|}{ White-collar } & \multicolumn{2}{|c|}{ Blue-collar } \\
\hline & Symptoms & Findings & Symptoms & Findings \\
\hline \multicolumn{5}{|c|}{ Neck, shoulders, upper limbs } \\
\hline \multicolumn{5}{|l|}{ Men $^{\mathrm{a}}$} \\
\hline Work content & -0.02 & 0.11 & -0.03 & 0.11 \\
\hline Work control & -0.02 & 0.00 & -0.08 & 0.04 \\
\hline Social relations & $0.24^{* *}$ & 0.03 & 0.14 & $0.16^{*}$ \\
\hline Overstrain & $0.18^{*}$ & -0.09 & 0.03 & 0.08 \\
\hline \multicolumn{5}{|l|}{ Women ${ }^{b}$} \\
\hline Work content & 0.13 & -0.03 & 0.01 & 0.06 \\
\hline Work control & 0.03 & $0.28^{* *}$ & 0.17 & 0.17 \\
\hline Social relations & -0.03 & 0.04 & 0.05 & 0.05 \\
\hline Overstrain & -0.18 & 0.16 & 0.21 & 0.05 \\
\hline \multicolumn{5}{|l|}{ Low back } \\
\hline \multicolumn{5}{|l|}{ Men $^{\mathrm{a}}$} \\
\hline Work content & 0.10 & 0.12 & 0.07 & $0.20^{* *}$ \\
\hline Work control & -0.06 & 0.02 & -0.05 & -0.06 \\
\hline Social relations & 0.14 & 0.14 & 0.21 ** & $0.27^{\star *}$ \\
\hline Overstrain & 0.09 & 0.04 & 0.05 & 0.13 \\
\hline \multicolumn{5}{|l|}{ Women $^{b}$} \\
\hline Work content & -0.10 & 0.08 & -0.04 & $0.24^{*}$ \\
\hline Work control & -0.12 & 0.08 & $0.36^{\star *}$ & $0.22^{*}$ \\
\hline Social relations & -0.06 & $0.21^{*}$ & 0.07 & $0.22^{\star}$ \\
\hline Overstrain & -0.08 & -0.11 & 0.08 & $0.24^{*}$ \\
\hline \multicolumn{5}{|l|}{ Lower limbs } \\
\hline \multicolumn{5}{|l|}{ Mena $^{\mathrm{a}}$} \\
\hline Work content & 0.04 & 0.00 & -0.02 & $0.15^{*}$ \\
\hline Work control & 0.02 & -0.08 & 0.03 & -0.06 \\
\hline Social relations & $0.20^{*}$ & 0.14 & $0.20^{* *}$ & 0.10 \\
\hline Overstrain & 0.14 & 0.01 & 0.07 & 0.04 \\
\hline \multicolumn{5}{|l|}{ Women' } \\
\hline Work content & $0.22^{*}$ & -0.01 & -0.19 & $0.24^{*}$ \\
\hline Work control & 0.16 & -0.04 & 0.11 & 0.22 \\
\hline Social relations & $0.31^{* *}$ & $0.23^{\star}$ & 0.11 & $0.32^{* \star}$ \\
\hline Overstrain & -0.00 & -0.01 & 0.14 & 0.19 \\
\hline
\end{tabular}

a Number of subjects: white collar: 117, blue collar: 149 .

b Number of subjects: white collar: 83, blue collar: 62 .

cal features of the work could lend themselves to more objective measurement. Frese (17) considered the relationship between stress at work and psychosomatic complaints in blue-collar workers. He analyzed subjective reports and observer's estimates of psychological stress at work. The associations between stress and complaints persisted on a statistically significant level also when objective stress measures were used.

Among the subjects of our study, it had previously been observed that reports of work content and physical work environment improved among the employees who were promoted or who changed employer, as compared with those who stayed in the same job (18). Changes in work content and the work environment predicted changes in job stress and general distress. The results imply that a subject's perceptions of psychosocial job factors are not invariant, but are influenced by changes in objective work conditions.

The prospective part of our study allowed us to investigate the chronological order of the predictors and their assumed health effects. Poor satisfaction with the social relationships at work was antecedent to an increase in musculoskeletal morbidity. Bigos et al (12) showed that satisfaction with social interaction with workmates predicted the reporting of back injury in a four-year followup. Riihimäki et al (13) observed that problems with workmates or superiors increased the three-year incidence of sciatic pain among male office workers. Our results also show that a change in clinical findings in the low back, as well as in the morbidity of the neck, shoulder and the upper-limb area and of the lower limbs, are predicted by the quality of social interaction at work. The psychological content of work seems also to be impor- 
Table 6. Multiple regression models of overall musculoskeletal morbidity at the beginning of the study and at follow-up. Standardized regression coefficients. Total sample.

\begin{tabular}{|c|c|c|c|}
\hline & Beta & $T$ & $P$ \\
\hline \multicolumn{4}{|l|}{ Beginning of study } \\
\hline \multicolumn{4}{|l|}{ Symptoms $\left(R^{2}=0.220\right)$} \\
\hline $\begin{array}{l}\text { Age } \\
\text { Overstrain } \\
\text { Work content } \\
\text { Gender } \\
\text { Physical load } \\
\text { Occupational class }\end{array}$ & $\begin{array}{l}0.310 \\
0.208 \\
0.164 \\
0.134 \\
0.127 \\
0.090\end{array}$ & $\begin{array}{l}9.95 \\
6.63 \\
4.65 \\
4.12 \\
3.10 \\
2.14\end{array}$ & $\begin{array}{l}0.000 \\
0.000 \\
0.000 \\
0.000 \\
0.002 \\
0.033\end{array}$ \\
\hline \multicolumn{4}{|l|}{ Findings $\left(R^{2}=0.229\right)$} \\
\hline $\begin{array}{l}\text { Age } \\
\text { Work content } \\
\text { Gender } \\
\text { Overstrain } \\
\text { Occupational class } \\
\text { Physical load }\end{array}$ & $\begin{array}{l}0.395 \\
0.129 \\
0.125 \\
0.123 \\
0.099 \\
0.091\end{array}$ & $\begin{array}{r}12.73 \\
3.69 \\
3.87 \\
3.95 \\
2.36 \\
2.23\end{array}$ & $\begin{array}{l}0.000 \\
0.000 \\
0.000 \\
0.000 \\
0.019 \\
0.026\end{array}$ \\
\hline \multicolumn{4}{|l|}{ Follow-up } \\
\hline \multicolumn{4}{|l|}{ Symptoms $\left(R^{2}=0.356\right)$} \\
\hline $\begin{array}{l}\text { Initial symptoms } \\
\text { Gender } \\
\text { Occupational class } \\
\text { Social relations } \\
\text { Age }\end{array}$ & $\begin{array}{l}0.428 \\
0.225 \\
0.112 \\
0.110 \\
0.103\end{array}$ & $\begin{array}{l}9.89 \\
5.42 \\
2.67 \\
2.63 \\
2.41\end{array}$ & $\begin{array}{l}0.000 \\
0.000 \\
0.008 \\
0.009 \\
0.016\end{array}$ \\
\hline \multicolumn{4}{|l|}{ Findings $\left(R^{2}=0.307\right)$} \\
\hline $\begin{array}{l}\text { Initial findings } \\
\text { Age } \\
\text { Occupational class } \\
\text { Social relations }\end{array}$ & $\begin{array}{l}0.355 \\
0.314 \\
0.159 \\
0.146\end{array}$ & $\begin{array}{l}8.33 \\
7.27 \\
3.73 \\
3.41\end{array}$ & $\begin{array}{l}0.000 \\
0.000 \\
0.000 \\
0.001\end{array}$ \\
\hline
\end{tabular}

tant in relation to the development of musculoskeletal morbidity.

There is a considerable lack of data on the possible mechanisms of the observed associations. Some forms of depression are assumed to be manifested as, for example, musculoskeletal pain (19). Mental stress may enhance the perception and reporting of symptoms (16). It has also been suggested that raised muscle tension, a corollary of several emotions and anxiety, could be a mediator between psychological states and musculoskeletal pain (20).

Theorell et al (21) found that psychological job conditions (notably demands) were associated with emotional states (notably worry). They also showed that several emotional states were associated with self-reported muscle tension, which was in turn associated with symptoms from the back, neck, and shoulders. Flor et al (22) provided further evidence of the role of muscular responses to stress in back pain. They demonstrated an abnormal paravertebral muscle reactivity in electromyographic recordings of patients with chronic back pain in experimental situations in which personally relevant stressors were used. The response was associated with depression and worry but not with organic derangement of the back.

In our investigation the observed associations were independent of physical work load and persisted when sociodemographic factors were taken into account. Their
Table 7. The 10-year correlations of the work-load indices by gender and occupational class.

\begin{tabular}{lccccc}
\hline Index & \multicolumn{2}{c}{ Men } & & \multicolumn{2}{c}{ Women } \\
\cline { 2 - 3 } \cline { 5 - 6 } & $\begin{array}{c}\text { White- } \\
\text { collar }\end{array}$ & $\begin{array}{c}\text { Blue- } \\
\text { collar }\end{array}$ & & $\begin{array}{l}\text { White- } \\
\text { collar }\end{array}$ & $\begin{array}{c}\text { Blue- } \\
\text { collar }\end{array}$ \\
\hline Work contenta & $0.63^{* *}$ & $0.26^{* *}$ & & $0.56^{* * *}$ & 0.24 \\
Work control & $0.48^{* * *}$ & $0.20^{*}$ & & $0.35^{* *}$ & $0.30^{*}$ \\
Social relations & $0.34^{* * *}$ & $0.27^{* *}$ & & $0.52^{* * *}$ & 0.19 \\
Overstrain & $-0.03^{* *}$ & $-0.17^{*}$ & & -0.21 & -0.00 \\
Physical load & $0.35^{* *}$ & $0.34^{* *}$ & & $0.39^{* *}$ & 0.19 \\
\hline
\end{tabular}

a Based on five items.

${ }^{*} P<0.05$, ** $P<0.01$, *** $P<0.001$.

strength was dependent on the age of the employees in the cross-sectional analyses. It is possible that the personal significance of various stressors and the ability to cope with them vary by phase of life.

Physical work load was less consistently associated with morbidity than some of the psychosocial factors were. The associations were weakened due to selective movement of workers with musculoskeletal problems from physically strenuous work to less demanding tasks or to outside the work force (23). The selective processes that involve psychosocial aspects of work are probably weaker.

The coefficients of determination of the models were higher prospectively than at the beginning of the study. This was mainly due to the fact that earlier morbidity was a strong predictor of later morbidity. This finding can be interpreted as an idiosyncratic factor, representing constitutional influences. On the other hand, earlier morbidity is also the carrier of earlier environmental effects, to the extent that they are not reversible.

\section{References}

1. Mäkelä M. Common musculoskeletal syndromes: prevalence, risk indicators and disability in Finland. Helsinki: Social Insurance Institution, 1993. Publications of the Social Insurance Institution, ML:123.

2. Bongers PM, de Winter CR, Kompier MAJ, Hildebrandt VH. Psychosocial factors at work and musculoskeletal disease. Scand J Work Environ Health 1993;19:297-312.

3. Weiser $\mathrm{S}$, Cedraschi C. Psychosocial issues in the prevention of chronic low back pain. Baillière's Clin Rheumatol 1992;6:657-84.

4. Magora A. Investigation of the relation between low back pain and occupation: V. psychological aspects. Scand J Rehabil Med 1973;5:191-6.

5. Dehlin O, Berg S. Back symptoms and psychological perception of work: a study among nursing aides in a geriatric hospital. Scand J Rehabil Med 1977;9:61-5.

6. Lehto TU, Helenius HYM, Alaranta HT. Musculoskeletal symptoms of dentists assessed by a multidisciplinary approach. Community Dent Oral Epidemiol 1991;19:38-44.

7. Bergenudd H, Nilsson B. Back pain in middle age; occupational workload and psychologic factors; an epidemiological survey. Spine 1988;13:58-60. 
8. Svensson H-O, Andersson GBJ. The relationship of low back pain, work history, work environment, and stress: a retrospective cross-sectional study of 38- to 64-year-old women. Spine 1989;14:517-22.

9. Winkleby MA, Ragland DR, Syme SL. Self-reported stressors and hypertension: evidence of an inverse association. Am J Epidemiol 1988;127:124-34.

10. Linton SJ. Risk factors for neck and back pain in a working population in Sweden. Work Stress 1990;4:41 - 9 .

11. Mäkelä M, Heliövaara $M$, Sievers K, Impivaara $O$, Knekt $P$, Aromaa A. Prevalence, determinants, and consequences of chronic neck pain in Finland. Am J Epidemiol 1991;134:1356-67.

12. Bigos SJ, Battié MC, Spengler DM, Fischer LD, Fordyce WE, Hansson T, et al. A prospective study of work perceptions and psychosocial factors affecting the report of back injury. Spine 1991;16:1-6.

13. Riihimäki H, Viikari-Juntura E, Moneta G, Kuha J, Videman $\mathrm{T}$, Tola S. Incidence of sciatic pain among men in machine operating, dynamic physical work, and sedentary work - a three-year follow-up. Spine 1994;19:138-42.

14. Leino P, Hänninen V, Toivonen L, Aro S, Telama R, Kirjonen $\mathrm{J}$, et al. Työolot, psyykkinen hyvinvointi, elintavat ja terveydentila metalliteollisuuden ammattiasemaryhmissä 1973-83 (METELI): Tutkimuksen tausta, asetelma ja toteutus [Working conditions, mental well-being, living habits, and health among occupational groups in the metal industry in 197383: study design and implementation]. Tampere: Kansanterveystieteen laitos, 1984. Kansanterveystieteen julkaisuja M

\section{Appendix 1}

\section{Indices used for psychosocial work load}

Work content (Cronbach's alpha coefficient $=0.86$ ):

"What is your work like?" ( 1 = interesting and varied, ... $5=$ very monotonous)

"How much strain does monotonous work put on you?" ( $1=$ none,$\ldots 5$ = very much)

"Are you satisfied with how interesting and varied your work is?" ( $1=$ very satisfied, $\ldots 5=$ very unsatisfied $)$

"Do you learn new things at work?" $(1=$ very often,.. $5=$ very seldom)

"Do you have opportunities to use your knowledge and skills at work?" $(1=$ very well, $\ldots 5=$ very badly)

"Do you feel that you could be replaced by anybody at work?" $(1=$ very seldom, $\ldots 5=$ very often $)$

\section{Work control $($ alpha $=0.66)$}

"How much information do you get about the production plans of your department or of the factory?" $(1=$ very much, ...5 = very little)
82/84. English summary.

15. American Academy of Orthopedic Surgeons. Joint motion method of measuring and recording. Chicago, IL: American Academy of Orthopedic Surgeons, 1965.

16. Leino P, Heiskanen T, Hasan J, On the specificity of musculoskeletal symptoms - a biosemiotic excursion. In: Sebeok TA, Umiker-Sebeok J, editors. The semiotic web, yearbook 1991. Berlin: Mouton de Gruiter, 1992:235-49.

17. Frese M. Stress at work and psychosomatic complaints: a causal interpretation. J Appl Psychol 1985;70:314-28.

18. Kirjonen J, Hänninen V. Getting a better job: antecedents and effects. Hum Relations 1986;39:503-16.

19. Leino P, Magni G. Depressive and distress symptoms as predictors of low back pain, neck-shoulder pain, and other musculoskeletal morbidity: a 10-year follow-up of metal industry employees. Pain 1993;53:89-94.

20. Ursin H, Endresen IM, Svebak S, Tellnes G, Mykletun R. Muscle pain and coping with working life in Norway: a review. Work Stress 1993;7:247-58.

21. Theorell T, Harms-Ringdahl K, Ahlberg-Hulten G, Westin B. Psychosocial job factors and symptoms from the locomotor system - a multicausal analysis. Scand J Rehabil Med 1991;23:165-73.

22. Flor H, Turk DC, Birbaumer N. Assessment of stress-related psychophysiological reactions in chronic back pain patients. J Consult Clin Psychol 1985;53:354-64.

23. Leino P, Hasan J, Karppi S-L. Occupational class, physical workload, and musculoskeletal morbidity in the engineering industry. Br J Ind Med 1988;45:672-81.

"Do you get to know in time about plans for changes in your work or at your department?" $(1=$ mostly, . . . $5=$ very seldom)

"Are you able to influence changes at work?" ( 1 = very much, ...5 = very little)

"How satisfied are you with the attitude of the management of the factory?" ( 1 = very satisfied, . . . 5 = very unsatisfied)

\section{Social relationships (alpha $=0.73$ )}

"How satisfied are you with your supervisor?" (1 = very satisfied, . . 5 = very unsatisfied)

"Is your supervisor able to appreciate the difficulties of your work?" (1 = very well, . . .5 = very badly)

"Does your supervisor take your personal problems into account?" ( $1=$ mostly, . . 5 = seldom $)$ 
"Does your supervisor treat you justly?" ( 1 = mostly, .. . $5=$ seldom $)$

"How satisfied are you with your workmates?" (1 = very satisfied, . . .5 = very unsatisfied)

"Are there arguments between personnel groups at your workplace?" ( $1=$ never, . . . 5 = very often $)$
Overstrain (alpha $=0.60)$

"How mentally strenuous do you consider your work?" ( 1 = very little, $\ldots 5$ = very much)

"Do work concerns weigh on your mind at home?" ( 1 = very little, $\ldots 5$ = very much)

"Are you overstrained by your work?" ( 1 = very little, .. $.5=$ very much)

\section{Appendix 2}

\section{Indices used for musculoskeletal morbidity}

\section{Symptoms}

In the questionnaire it was asked: "Have you felt ache, stiffness, sensitivity to movement, numbness, or pain in joints or muscles in the locations listed below, and how often, during the past 12 months?" The list included the following locations: (i) shoulder, upper arm, (ii) elbow, forearm, (iii) wrist, hand, fingers, (iv) hip joint, (v) thigh, (vi) knee, (vii) calf, (viii) ankle, foot, (ix) sole, toes, $(\mathrm{x})$ neck, cervical and occipital region, (xi) radiation of cervical pain to the arm, (xii) thoracic region, (xiii) lumbosacral region, (xiv) radiation of lumbosacral pain to the leg. Each item was scored from 1 (never) to 4 (often or continuously). The right and left sides were recorded separately. Low-back symptoms comprised items xiii-xiv. Neck, shoulder and upperlimb symptoms were determined from items $\mathrm{i}-\mathrm{iii}$ and $\mathrm{x}$-xi. Lower-limb symptoms were evaluated from items iv-ix.

\section{Clinical findings}

Neck, shoulder and upper-limb findings: cervical spine and myalgia of the trapezius muscle, humeroscapular joint, myalgia of the upper arm, elbow joint, epicondylitis, myalgia of the lower arm, wrist, finger joints (empirical range $0-24$ ).

Low-back findings: the item as such (range 0-4).

Lower-limb findings: hip joint, myalgia of the thigh, knee joint, myalgia of the calf, ankle joint (range 0-16).

Overall sum scores were also constructed for both the symptoms and the findings.

Received for publication: 18 May 1994 